\title{
Introduction: Nothing in Return? Distinctions between Gift and Commodity in Contemporary Societies
}

\section{Michaela Benson and Denise Carter}

According to Mauss' seminal works, it was through obligations laid bare by the gift exchange process - the obligation to give, receive and reciprocate-that pre-modern societies were symbolically reproduced. Mauss' distinction between those early societies and the encroaching capitalist world has led to questions about whether gift exchange can play a similar role in today's highly individualised and impersonal contemporary societies. In addition, it has also stimulated a great deal of debate about the relationship between gifts and commodities. If, as many theorists suggest, commodities are a central feature of daily life in capitalist societies, there is the possibility of fluidity between gift and commodity. This invites several interesting questions about the forms and functions of exchange: what forms does exchange take in contemporary societies; what implications, if any, do these forms of exchange have for relationships in contemporary society; and, does gift exchange still have a function in society?

This special issue draws attention to these questions and further interrogates the intersection of gift and commodity using empirical examples within contemporary societies. From kidney transplant to gifting money, each of our selected papers demonstrates it is not an easy task to define some objects as gift and others as commodity. Rather, there are occasions where one transforms into the other (Carrier 1995), and many objects involved in exchange transactions possess characteristics of both gift and commodity. This reflects Laidlaw's (2000) argument that gift and commodity are not necessarily opposed to one another; instead they are continually reconfigured within an intricately contextual relationship. The point at which an object is predominantly gift or commodity relates both to the context of its exchange and to the nuances of the social relationship between the giver and the recipient. As a result, we must remain aware that objects involved in exchange transactions may have characteristics of both gift and commodity, and may be variously expressed across different times and in different situations.

This special issue provides an opportunity to consider the true complexity of exchange within contemporary society and examine transformations in the significance of the objects at the basis of exchange. In other words, we pose the questions, what circumstances give rise to the exchange of gifts rather than commodities, and does an object that is once a gift always remain a gift, or can it similarly/simultaneously operate as a commodity? Equally, articles in this issue question those diverse occasions when a range of commodities are transformed into gifts. The central focus of all the papers is the examination of the social relationships that may, or may not, result from exchange. This leads authors to question which forms of exchange are relevant for the social integration of modern society, as gift exchange was for Mauss' pre-moderns. 


\section{Exchanging Gifts}

In Marcel Mauss' (1990) seminal text The Gift, he stressed that gift-giving was a central feature in constructing, maintaining and reproducing enduring social relationships. Although he discussed gift exchange in pre-capitalist societies, it is possible that the exchange of gifts in contemporary society may also be explained in the same way. It is with this in mind that we claim Sahlins' statement, 'If friends make gifts, gifts make friends' (1972: 186) would go unchallenged in the Western world and thus could be considered as a representative statement in respect to our own gift-giving practices. And this is not simply about presents, wrapped and tied with a bow, there are a variety of other objects, 'things' which can be considered as ' $g i f t$ '. For example, the articles in this issue present time, money, and even bodily organs for consideration under the rubric of the gift.

As Mauss' (1990) noted, there are a series of obligations to which gift giving pertains. First, there is the obligation to give, presupposing a social relationship between the giver and the recipient. Second, there is the obligation to receive; rejection of the object given could result in the termination of the existing relationship. Finally, Mauss' (1990) stated that there is an obligation to reciprocate, to give in return. By accepting the gift, the recipient is obliged to re-enter the cycle as a giver. The recognition of these objectives, particularly the first one, is indicative of the social relationship between the giver and the recipient. Reaction to the giving of the gift by the recipient determines how the relationship will proceed. It seems that there is a fine line to tread when it comes to the complex social process that is gift exchange. As Mauss argued, 'To refuse to give, to fail to invite, just as to refuse to accept, is tantamount to declaring war; it is to reject the bond of alliance and commonality' (1990: 13).
While this system of exchange may, on one level, appear voluntary, it is apparent in Mauss' interpretation that it also has obligatory elements. The paradoxical nature of the gift is what helps to perpetuate the system. As Laidlaw, in a review of Mauss' work explains,

Gifts evoke obligations and create reciprocity, but they can do this because they might not: what creates the obligation is the gesture or moment which alienates the given thing and asks for no reciprocation (2000: 628).

It seems that the adage, 'don't give to receive' is representative of the paradox of gift giving in contemporary Western society. While there is an implicit recognition of the obligations entailed in the system of gift exchange-it is the 'right' thing to give a gift in return-and we are aware of the consequences of not reciprocating or taking part, there is also a dominant discourse which states that gift-giving should be done for unselfish purposes. It seems that altruism remains a central feature of our beliefs about gifts, even if our actions suggest otherwise. This selflessness is similarly a feature of the 'pure gift' that lies at the centre of Mauss' works.

As Laidlaw (2000) explains, the characteristics of the 'pure gift' resonate with those of the free gift (see for example Parry 1980, 1986, $1989,1994)$ that entails no personal connections and therefore no obligations. The 'free' or 'pure gift' is impersonal, a feature that is maintained, as Copeman (2000) argues, because of the lack of recognition from the recipient towards the donor. The pure gift is thus altruistically given. There is no expectation of reciprocation and the donor is alienated from the object that they give.

According to Mauss (1990), this 'no strings attached' approach to gift does not result in social relations because it does not create obligations between people. Indeed, the discourse behind the donation of blood and organs in contemporary society highlights this alienation. 
Relationships between donors and recipients are not encouraged; the object exchanged is both anonymously given and received and thus has, at least at first sight, the characteristics of the 'pure gift'. However, as Titmuss (1970) argues, this exchange is not so clear-cut. There are many expectations, particularly from the donor, which would highlight that this is not such a selfless act after all. For example, the donor may have the expectation that they will receive blood should they need it.

The expectation of reciprocation and the examination of individual motivations-the particular contexts of blood donation-can determine the extent to which it is involved in a process that could be characterised as gift exchange. It is not our intention here to discuss the intricacies of organ and blood donationindeed Shimazono in this issue examines kidney donation in greater detail-we only use this example to highlight that the 'pure gift' is never easily identified. It may be that blood donation is a clear example of how fluid the gift can be.

\section{The Intersections of Gift and Commodity Exchange}

Strathern (1988) draws attention to the fundamental differences between gift exchange and commodity exchange. As she explains, while gift exchange works to draw attention to relationships that already exist, in commodity exchange, people are apparent in and of themselves. In other words, gift giving prepares the ground for others to act-through the various obligations that it entails-while in commodity exchange, obligations are not necessary because people act independently.

The distinction between these two forms of exchange is undoubtedly useful, but what happens in cases when it is not clear whether gift exchange or commodity exchange is occurring? Indeed, an action that we might assume to be commodity exchange, such as buying food, could soon be seen in a different light if, for example, we recognise that people expect something in return for their loyalty to particular supermarkets. Hence the prevalence of supermarket 'points' cards which allow customers to collect points which can later be redeemed for money off their shopping or particular products, with supermarkets encouraging the idea among their customers that they are being rewarded for their loyalty. Grocery shopping is not, in this interpretation, an example of 'pure' commodity exchange. Instead, the loyalty cards play on notions of gift exchange helping to produce a sense of loyalty, an obligation to return. As Carrier argues, 'these qualifications do not contradict the point that commodities are impersonal. Instead, they show that not everything that we buy and sell is pure commodity' (Carrier 1995: 29). The expectation that there will be something in return presupposes the establishment of an enduring relationship between the vendor and the buyer, a relationship normally assigned to gift exchange rather than commodity exchange.

It is not only the establishment of a relationship that indicates the flux between commodity and gift; Carrier (1995), for example, discusses how commodities are interchangeable, despite the fact that they must be exchanged on equal grounds and, ultimately, for equal value. One example that he gives is the exchange of works of art where the artist is an important consideration in determining the 'value' (monetary or otherwise) of a particular work. This consideration of the 'value' of the exchange highlights that commodity transactions often have features ordinarily reserved for the discussion of gift. The idea that the two objects are of equal value resonates with discussions of the Kula exchange, where the participants have to consider what they reciprocate with. As Weiner (1976) explains, there is an expectation within the system that the object given in return will be at least equal in value to the original. This perpetu- 
ates the social relationship, while failure to reciprocate in kind may result in damage or its termination. More to the point, the process encourages a sense of obligation. The failure to recognise obligation and ideas of reciprocation within arenas generally associated with commodity exchange rather than gift exchange undermines the complexity of exchange transactions within the contemporary world that the articles in this special issue emphasise.

Although there has been a concern with the definition of the pure gift (Laidlaw 2000) and its distinction from the pure commodity (see for example, Carrier 1990, 1995), it seems that there has been very little interrogation of those objects which fall in between these two positions; objects which at one time adopt the features of the gift, while at other times taking on the characteristics of a commodity. This necessarily relies on context, as the articles in this issue demonstrate; what is indeed intended by the exchange, but also how it is perceived and reacted to by the receiver of the object. Similarly, there are also cases where commodity becomes gift by entering into the social relationships between people. Through use, commodities may be transformed.

\section{Transformative Cultural Work}

So, how does an object become a gift? As Carrier (1990) argues, in contemporary society, the objects that we use to perpetuate our social relationships are most likely to have been purchased as commodity. Somehow the impersonality of objects, reflected both at the level of production and at the point of purchase, has to be overcome for the object to be successful within gift exchange. Through the exchange, within a personal relationship, the object, as Carrier (1990) argues, gains personality. This highlights how an object may be considered as 'a culturally constructed entity endowed and reclassified into culturally constituted categories' (Kopytoff 1986: 68), personalised to reflect a particular situation. This echoes the idea in common circulation that gifts should be meaningful, a symbol of the relationship between the giver and the receiver. In this respect, they are not anonymous or impersonal, but this does not mean that in a different relationship, under different circumstances, that the object would mean the same thing.

The transformation of a commodity, an alienated good, into a personal possession eligible to act as a gift, 'an extension of the self in a way that mere property is not' (Carrier 1990: 582), requires cultural work. This transformation of commodity to gift may occur as a result of how individuals experience and understand the production and sale of the objects involved. For example, if an object is bought in a more personalised environment, some of the cultural work involved in the transformation has already been done (Carrier 1990). Goddard (2000) raises a similar point, drawing parallels between Weiner's (1984) discussion of how objects are inscribed with spells and the way that commodities are transformed through inscription. It is thus that, 'a previously alienated object can be appropriated and re-presented as somehow intrinsically related to a new subject' (Goddard 2000: 148). The examination of the process of inscription therefore allows further understanding of how gift and commodity economies interact with one another.

The degree to which the gift needs to be personally possessed reflects the amount of work it is to do. This is directly correlated to the extent of the relationship that it emerges from. The point here is not to deny that 'gift' and 'commodity' are distinct from one another (cf. Goddard 2000), but to stress that it is necessary to question how through appropriation and possession, commodities are transformed into 'gifts'.

The question remains, what is involved in the transformation of commodity to gift? 
Spending time, energy and thought (after all, it is the thought that counts) is one way that people claim possession of an object. In this manner, they make the object more personal to them, they imbue it with a sense of their personal identity. As Mauss outlined, 'objects are never completely separated from the men who exchange them' (1990: 31). The implications of this are that the giving of a gift establishes a bond between the donor and the recipient. It is through the examination of the relationships involved in exchange that the papers in this special issue interrogate the extent to which contemporary forms of exchange can be considered under the rubric of gift exchange.

\section{The Empirical/Applied Perspective}

Each of the papers in this collection elaborates on these issues and questions from an empirical and applied perspective to investigate what counts as gift exchange in the contemporary social world and where it can be found. Answers are found in these examinations of the gift of charity; gifts and reciprocity in local and national relations; organ donation/transplantation technologies and gift exchange in cyberspace.

Jo Cook examines the part that women, in the role of Buddhist nuns (mae chee), now take in the Buddhist practice of alms donations. Having renounced the world, mae chee employ both the ascetic practices of accepting alms (as renouncers) and offering alms (as laity). In addition, mae chee also receive and process monetary alms from the laity on behalf of the monastic community as a whole. Cook argues that by handling money given to the monastic community mae chee mediate in a relationship of generalised reciprocity between the monastic community and lay society. By standing both inside and outside of the monastic community, mae chee offer this empirical study an intriguing view of gift practices as they are related to interpersonal and group dynamics in the context of modern Thai monasticism.

Abel Polese challenges our understanding of bribery and corruption in post soviet Ukraine. His paper proposes that most of the 'economic transactions' that are reported as bribe taking have a deeper meaning and can be analysed within the framework of gift exchange proposed by Marcel Mauss. Focussing on three of the alleged most 'corrupted' places in Ukraine: a university, a hospital and a police control post, Polese develops a detailed analysis of the meanings behind these transactions and recognises how defining some of those exchanges as corrupt might lead to the phasing out of some local traditions of social and economic interaction.

Yosuke Shimazono explores whether livingrelated kidney transplantation in the Philippines can be considered as gift exchange. Two aspects of the gift relationship-the relationship between the donor and the recipient and the relationship between the recipient and the object-and two kinds of acts-'acknowledging the debt/repaying the gift of life' and 'taking care of a kidney/cherishing the gift' - are described and examined. This article demonstrates that there is a persisting internal tension in live kidney transplantation between the logic of the Maussian or 'archaic' gift and that of the gift based on the cultural ideal of familial love, where keeping and repaying the gift are not two independent acts but merge in the act of cherishing the gift.

In the final article of this special issue, Denise Carter investigates how the function and meaning of gift-exchange has emerged as being an important anthropological tool for the investigation of social relations online. She elucidates several fascinating questions, for example: what kinds of gifts are exchanged in cyberspace; how are these gifts exchanged there; and what does the exchange of gifts in cyberspace signify? This article draws on Carter's ethnography of a virtual community 
to examine the function and meaning of gift exchange in cyberspace in relation to contemporary theoretical notions of the gift. Her paper examines what kinds of obligations gifts engender, and what role gift practices play in creating networks of friendship in cyberspace. Central to this analysis is the 'gift of time' that can also be fed back into wider discussions about modernity and the routinisation and universalisation of time.

This special issue provides an opportunity to consider the true complexity of exchange within contemporary society and examine transformations in the significance of a variety of objects at the basis of exchange. From the gifting of alms to post soviet corruption, from the donation of body parts to the gift of time in cyberspace, this issue examines diverse occasions where a range of commodities are transformed into gifts. From a clear empirical and applied anthropological perspective it emerges that these forms of exchange are as relevant for modern society as gift exchange was for Mauss' pre-moderns. Even in today's highly individualised and impersonal contemporary societies, social relations are being symbolically reproduced. Collectively, these papers illuminate how the gift exchange process still functions in contemporary society albeit across different times and in different situations. We hope that the papers stimulate some reflection about the nuances of gift exchange in modern society, and kindle a desire to understand the potential impact on the continuing transformation of social life.

Michaela Benson is the current Sociological Review Fellow, based at Keele University. She is also a visiting fellow in the Sociology Department, University of Bristol. Her research focuses on lifestyle migration, and she is currently in the process of writing a monograph based on her research among the British residents of the Lot department, France. She was awarded her PhD in Sociology and Social Anthropology from the University of Hull in 2008.
Denise Maia Carter has a PhD in Social Anthropology from the University of Hull. Her research interests focus on the social and cultural aspects of Information Communications Technologies, especially with assessing and identifying the risks to children and young people with using a wide range of digital technologies. She is also interested in the relationship between online and offline life, and the implications of ICT use for contemporary notions of friendship and community, sociability and social capital. Denise is also a member of the DCFS Cyberbullying Taskforce, and at a European level is a member of the EU INSAFE Project cyberbullying workgroup. Denise is currently involved in educational projects with a number of mobile and Internet service providers, and with European Schoolnet.

\section{References}

Carrier, J. (1990), 'Reconciling Commodities and Personal Relations in Industrial Society', Theory and Society, 19, no. 5: 579-598.

----.. (1995), Gifts and Commodities: Exchange and Western Capitalism Since 1700 (London: Routledge).

Copeman, J. (2005), 'Veinglory: Exploring Processes of Blood Transfer between Persons', The Journal of the Royal Anthropological Institute (N.S.), 11: 465-485.

Goddard, M. (2000), 'Of Cabbages and Kin: the Value of an Analytic Distinction between Gifts and Commodities', Critique of Anthropology, 20, no. 2: 137-151.

Kopytoff, I. (1986), 'The Cultural Biography of Things: Commoditization as Process' in The Social Life of Things (ed.) A. Appadurai (New York: Cambridge University Press).

Laidlaw, J. (2000), 'A Free Gift Makes No Friends', The Journal of the Royal Anthropological Institute, 6, no. 4: 617-634.

Magazine, R. (2003), 'Action, Personhood and the Gift Economy Among So-called Street Children in Mexico City', Social Anthropology, 11, no. 3: 303-318.

Mauss, M. (1990), The Gift (London: Routledge).

Parry, J. (1980), 'Ghosts, Greed and Sin: the Occupational Identity of the Benares Funeral Priests', Man (n.s.), 15: 88-111. 
Parry, J. (1986), 'The Gift, the Indian Gift and the "Indian Gift"', Man, 21: 453-473.

Parry, J. (1989), 'On the Moral Perils of Exchange', in Money and the Morality of Exchange, (eds.) J. Parry and M. Bloch (Cambridge: Cambridge University Press).

Parry, J. (1994), Death in Banaras (Cambridge: Cambridge University Press).

Sahlins, M. (1972), Stone Age Economics (Chicago: Chicago University Press).
Strathern, M. (1988), The Gender of the Gift: Problems with Women and Problems with Society in Melanesia (Berkeley: University of California Press).

Titmuss, R. (1970), The Gift Relationship: from Human Blood to Social Policy (London: Allen and Unwin).

Weiner, A. (1976), Women of Value, Men of Renown: New Perspectives in Trobriand Exchange (Austin: University of Texas Press). 